\title{
New materials and products from synthetic textile waste: application of abductive reasoning in a design oriented process development
}

This paper presents a reflection on the applicability of abductive process, as proposed by Dorst (2011) for solving complex problems that involve the creation of value, and which are common to scientific research in the area of design. This reflection is performed in the context of the problem of synthetic textile waste from composite fabric made of polyamide 66 , generated by apparel industries. Considering the abductive process - 2 , the object being developed includes new material obtained from recycled waste above, as well as products that can be created from the new material. The principle refers to the process of development of new material and product. The value to be created unfolds in three main aspects: environmental, social and economic values. As a methodological approach, we used literary criticism about the problem and possible solutions, including the creation of new materials and a case study of a Brazilian garment company. Literary criticism also included scientific approaches in design research: deductive, inductive and abductive, specially the work of Dorst (2011). As a result, it is presented a diagram with a framework model of the problem based on the abductive thinking -2 , which will be used later along the development of a doctoral thesis on the topic.

keywords new materials, synthetic textile waste, abductive process, design process

Introduction

1. The problem of textile waste in the garment sector

The production of synthetic fabrics has shown significant growth in recent years worldwide, spurred by increased consumption, with different environmental impacts, as $\mathrm{CO}_{2}$ emissions and the depletion of non-renewable natural resources.

In the UK, for example, annually 1.12 million tons of clothes (30 kg / capita) are discarded, (Allwood et al, 2006 in WRAP, 2010), representing about $8 \%$ of the total weight of household waste (Oakdene Hollins Ltd et al, 2006 in WRAP, 2010). Of this amount, 350,000 tonnes ( $31 \%$ ) go to landfills, $47 \%$ are reused in other countries (34\%) or in the UK itself (12\%), $14 \%$ is recycled and $7 \%$ is incinerated (WRAP, 2012).

The world's largest apparel producers are China (49\%), followed by India (7\%), Pakistan (3.8\%) and Brazil (2.9\%), according to ABRAVEST (2010). SEBRAE (2004) estimates the average waste generation by the 26.000 Brazilian industries to be about $1400 \mathrm{~kg} / \mathrm{year}$ per company. The donation of waste is a common practice in the Brazilian garment industry, and there was in the last years an excess of waste offered in the market (MARTINS,

SAMPAIO, 2013). 


\section{Current approaches to end of life of textile waste}

The most common destinations for clothing discarded during production or postconsumption is the reuse, recycling, incineration and sending to landfill. Regarding the recycling of textile waste, Life Cycle Analysis (LCA) studies showed significant reductions in energy use (ERM, 2002 in WRAP 2012) and in emission of greenhouse gas (Korhonen \& Dahlbo 2007 in WRAP 2012;\& Dahlbo 2007 in WRAP 2012; Oakdene Hollins Ltd et $\mathrm{al}, 2006$ in WRAP, 2012). The benefits of recycling compared to incineration were also identified (ERM, 2006 in WRAP, 2012).

In general, recycling can occur in two ways (BASTIAN, 2009, p.78): in or out of the process. In this sense, the creation of new materials from recycled textile waste involves recycling out of the process as the materials to be developed are not necessarily incorporated back into the production of clothing. Instead, they can integrate other processes, such as products for construction industry, architecture, decoration, accessories, footwear, gardening and others.

In the case of synthetic textile materials, one difficulty for recycling is the variety of materials available, being polyester and polyamide the most significant. A study done by Nike (2013) pointed polyamide 66 as the worse environmental performance material among the 25 most commonly used materials for the company.

Nevertheless, there are already initiatives for recycling polyamide 66 , as reported by Bodrero, Canivenc and Cansell (1999), Booii, Hendrix and Frentzen (1997), Frentzen, Thijert and Zwart (1997), Kasserra (1998), and Sarian, Handerman, Adbye and Jones (1998). Polyamide 66 (trade name nylon 66) is used in the manufacture of various compound fabrics such as Lycra, Cordura, Coolmax, Thermolite and Supplex that use different materials in its composition, which further complicates recycling. They are widely used by Brazilian manufacturers of clothing; however, there is not an adequate knowledge on how to properly dispose this waste material.

\section{Supplex waste: Case study in a Brazilian garment company}

A recent study by Brazilian researchers ${ }^{1}$ in a company of Londrina, Paraná, indicated the waste of raw materials, lack of proper disposal and lack of appreciation of the waste as major problems concerning the use of Supplex ${ }^{2}$. The waste were usually donated to artisans, or collected by a collection company, which was responsible for the destination (MARTINS; SAMPAIO; PEREZ, 2013). This study had its emphasis on the role of design to solve these problems, and allowed the research team to understand that the challenge required expertise of other areas.

So, a partnership with the Department of Chemistry at UEL was established with the aim of developing new forms of synthetic textile waste recycling and possibly the creation of new materials for various applications. This partnership has been particularly successful, and initial results indicated that the Supplex is a challenging recycling material, and that

\footnotetext{
' This study integrated the research project 7945, developed at the Department of Design, State University of Londrina - UEL (Paraná, Brazil), in partnership with Mulher Elástica, a Brazilian garment company from Londrina, Paraná (MARTINS; SAMPAIO; PEREZ, 2013).

2Supplex is a product of Invista Inc., made of composite fabric, made of polyamide 66 and elastane (BRESLIN, 2014).
} 
this can be done in an environmentally appropriate manner. These results are in the process of intellectual protection, and should be disclosed so that this phase is completed.

\section{The design and creation of new materials}

The creation of new materials and products from synthetic textile waste includes many aspects. Some are objective and technical, productive, environmental and economic, and other subjective, related with human issues. The design is specifically a human activity that seeks to mediate all these aspects in order to develop the best possible answers in terms of economic viability, technical feasibility, social acceptability and environmental responsibility.

For this reason, we propose in this paper the design activity as guiding the development of new materials and products from synthetic textile waste, in an interdisciplinary action with other areas of knowledge such as chemistry and engineering materials. We based our study on the Dorst (2011) approach for design research problems.

\section{Abductive reasoning and the preliminary conceptual framework}

Dorst (idem) explains the problems in the natural sciences can usually be described by a simplified schematic such as the one on Figure 1:

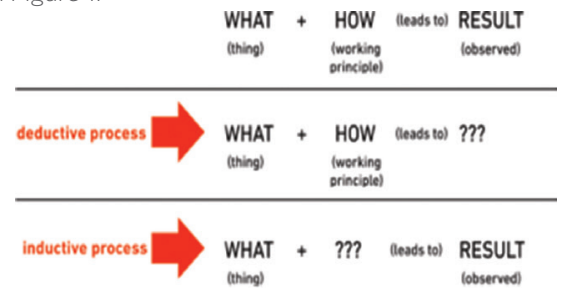

Figure 1. Simplified scheme of the problem when seeking an observable discovery (adapted from Dorst, 2011, p. 523).

In this model, the discovery can be the result of the interaction between the object and the functional principle (deductive process) or, alternatively, seek to identify empirically the functional principle, having previously the knowledge of the object and the result (inductive process). It is from these two types of reasoning that hypotheses are constructed to be confirmed or refuted by the natural sciences (Figure 1).

WHAT

(thing)

HOW (working
orinciole)

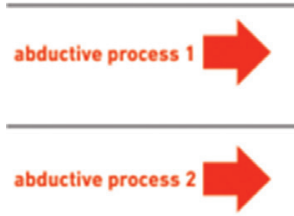

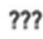

(twing)

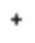

(wors

(work

??? (thing)

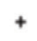

$+$ (working principle)

??? (leads to) VALUE

(aspired)

Research in the area of design, however, has characteristics that differentiate them from other areas of knowledge. Dorst (2011) explains that it is common for research in design to have diffuse problems, which hinders the use of deductive and inductive approaches. Furthermore, the design research is not a discovery, but the production of a certain value, which can be for a person, an organization, or even the planet (Figure 2).

Figure 2.

Simplified scheme of the problem when seeking to create value (adapted from Dorst, 2011, p. 523). 
theme 4

technology

Figure 3. Simplified scheme of the problem when seeking an observable discovery (adapted from Dorst, 2011, p. 523). strand 2

materials, techniques and processes

In this sense, we realize that the issue of this research falls within the "abductive process 2", as both the object (new material and products) and the functional principle (development process) are unknown. Thus, we propose a model approach to the problem selected in this work as shown in Figure 3.

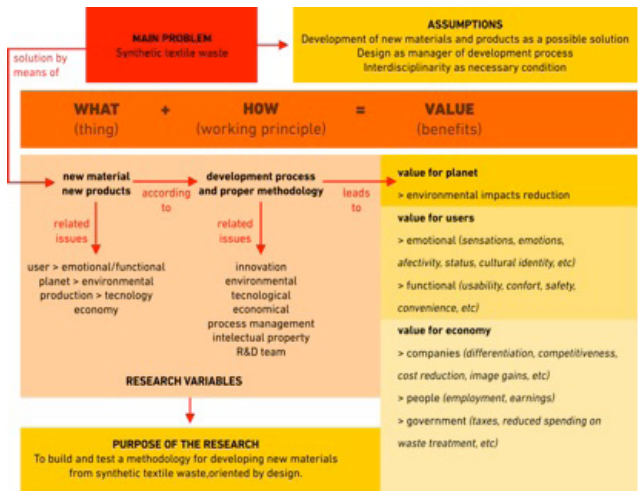

Whereas the previous model, the desired end result value includes environmental values (reduction of the environmental impact), user values (both emotional and functional ones) and economic values (e.g. differentiation, competitiveness, cost reduction and image gains). Following the model proposed by Dorst (2011) reasoning, the "how", or the principle of operation is reflected in the objective of designing and testing a methodology that enables the development of new materials with the reuse of synthetic textile waste -driven design. As for objects ("what"), these include both the development of a new material from the recycling of textile waste, as well as new products to be developed with this material.

\section{Conclusions}

This article focuses on the practical application of the abductive process proposed by Dorst (2011) to a problem of design research with complex characteristics, which is not known nor the "whys " or "hows " of the problem, but only the expected final values. This is a complex problem in which we seek a solution to the problem of synthetic textile waste through design, in an interdisciplinary way.

Regarding the built model, one of the biggest benefits of using it is the fact that it is supported by of a very simple formulation ( $w h a t+a s=$ value), from which the two variables are framed: the research object (new material and products), the principle of operation (methodology) and the expected values. The previous definition of these values also enabled visualization of several issues to be investigated.

In conclusion, it can be stated that the reasoning of the abductive type - 2 proposed by Dorst (2011) is helpful in framing the proposed problem, characterized as a typical problem of design research. One can also conclude that the construction of a model based on reasoning led to a simple and clear structuring of the research, and will be useful along the development of the design doctoral thesis of the author. 


\section{References}

Abravest, 2010. Dados Estatísticos do Setor Vestuário e Meias. Available at: http://www.abravest.org. br/index.php?option=com_content\&view=article\&id=49\&ltemid=30. [Accessed January 05, 2014].

Allwood et al, 2006 in WRAP, 2010. Final Report. Environmental benefits of recycling - 2010 update. March, 2010. available at: www.wrap.org.uk/clothing [Accessed January 05, 2014].

Bastian, E. Y. O., 2009. Guia técnico ambiental da indústria têxtil / Elaboração Elza Y. Onishi Bastian, Jorge Luiz Silva Rocco ; colaboração Eduardo San Martin ... [et al.]. - - São Paulo : CETESB : SINDITÊXTIL. 85 p. (1 CD) : il. col. ; 21 cm. - - (Série P + L, ISSN 1982-6648). ISBN 978-85-61405-08-3. Available at: http://www.cetesb.sp.gov.br/Tecnologia/producao_limpa/ documentos/textil.pdf [Accessed January 05, 2014].

Bodrero, S., Canivenc, E. and Cansell, F., 1999. Chemical Recycling of Polyamide 6.6 and Polyamide 6 through a Two Step Ami-/Ammonolysis Process, 4th Annual Conference on Recycling of Fibrous Textile and Carpet Waste, Dalton, GA, May 17-18.

Booij M., Hendrix J. A. J., Frentzen Y. H., 1997. Process for Recycling Polyamidecontaining Carpet Waste, European Patent 759456.

Breslin, E. What Is Supplex Nylon? Andrew Breslin, eHow Contributor. Available at: http://www. ehow.com/info_10007733_Supplex-nylon.html [Accessed January 05, 2014].

Defra's Maximizing Reuse and Recycling of UK Clothing and Textiles study 2009.

Dorst, K., 2011. The core of design thinking and its application. Design Studies, 32(6), pp.521-532. Available at: http://dx.doi.org/10.1016/j.destud.2011.07.006. [Accessed January 05, 2014].

ERM, 2002 in WRAP, 2012. Valuing our clothes - The true cost of how we design, use and dispose of clothing in the UK. WRAP. Valuing our clothes: the evidence base', WRAP, 2012, available at: www.wrap.org.uk/clothing [Accessed January 05, 2014].

ERM, 2006 in WRAP, 2012. Valuing our clothes - The true cost of how we design, use and dispose of clothing in the UK. WRAP. Valuing our clothes: the evidence base', WRAP, 2012, available at: www.wrap.org.uk/clothing [Accessed January 05, 2014].

Frentzen Y. H., Thijert M. P., Zwart R. L. 1997. Process for the Recovery of Caprolactam from Waste Containing Nylon by Extraction with Alkyl Phenol, World Patent 970304.

Kasserra H. P., 1998. Recycling of Polyamide 66 and 6, Science and Technology of Polymers and Advanced Materials, edited by P. N. Prasad et al., Plenum Press, New York, p. 629-635.

Korhonen \& Dahlbo 2007 in WRAP, 2012. Valuing our clothes - The true cost of how we design, use and dispose of clothing in the UK. WRAP. Valuing our clothes: the evidence base', WRAP, 2012, available at: www.wrap.org.uk/clothing [Accessed January 05, 2014].

Martins, S. B. ; Sampaio, C. P. ; Perez, I. U., 2013. Waste prevention and reuse of synthetic textiles: A case study in a Brazilian garment industry. In: 2nd International Conference On Sustainable Intelligent Manufacturing, 2013, Lisboa, Portugal. Proceedings Of The 2nd International Conference On Sustainable Intelligent Manufacturing. London, UK: CRC Press/Balkema, Taylor \& Francis Group, 2013. v. 1. p. 453-457.

Martins, S. B., Sampaio, C. P., 2013. Ampliação do ciclo de vida de resíduos sintéticos do setor de vestuário e aplicação em novos produtos. In Anais do $9^{\circ}$ Colóquio de Moda, Fortaleza, Ceará, Brasil. Available at: http://www.coloquiomoda.com.br/anais/anais/9-Coloquio-de-Moda_2013/ ARTIGOS-DE-GT/Artigo-GT-Moda-e-Sustentabilidade/Ampliacao-do-ciclo-de-vida-de-residuossinteticos-do-setor-de-vestuario-e-aplicacao-em-novos-produtos.pdf [Accessed January 05, 2014]. 
Oakdene Hollins Ltd et al, 2006 in WRAP, 2010. Final Report. Environmental benefits of recycling - 2010 update. March, 2010. available at: www.wrap.org.uk/clothing [Accessed January 05, 2014].

2012. Valuing our clothes - The true cost of how we design, use and dispose of clothing in the UK. WRAP. Valuing our clothes: the evidence base', WRAP, 2012, available at: www.wrap.org. uk/clothing [Accessed January 05, 2014].

Roozenburg, N. F. M., Eekels, J., 1995. Product design: Fundamentals and methods. Chichester, England: Wiley.

Sarian A. K., Handerman A. A., Jones S., Davis E. A. and Adbye A., 1998. Recovery of Polyamide from Composite Articles, US Patent 5849804.

SEBRAE. 2004. Metodologia Sebrae 5 menos que são mais: redução do desperdício. Available at: http://pt.scribd.com/doc/48806790/Metodologia-5 [Accessed January 05, 2014].

WRAP, 2010. Final Report. Environmental benefits of recycling - 2010 update. March, 2010. available at: www.wrap.org.uk/clothing [Accessed January 05, 2014].

2011. Valuing our clothes: the evidence base, WRAP, 2012, available at: www.wrap.org.uk/ clothing [Accessed January 05, 2014].

2012. Valuing our clothes - The true cost of how we design, use and dispose of clothing in the UK. WRAP. Valuing our clothes: the evidence base', WRAP, 2012, available at: www.wrap. org.uk/clothing [Accessed January 05, 2014]. 
